\title{
Materiality in Corporate Governance: The Statement of Significant Audiences and Materiality
}

\section{Citation}

Eccles, Robert G., and Tim Youmans. "Materiality in Corporate Governance: The Statement of Significant Audiences and Materiality." Harvard Business School Working Paper, No. 16-023, September 2015.

\section{Permanent link}

http://nrs.harvard.edu/urn-3:HUL.InstRepos:21444488

\section{Terms of Use}

This article was downloaded from Harvard University's DASH repository, and is made available under the terms and conditions applicable to Open Access Policy Articles, as set forth at http:// nrs.harvard.edu/urn-3:HUL.InstRepos:dash.current.terms-of-use\#OAP

\section{Share Your Story}

The Harvard community has made this article openly available.

Please share how this access benefits you. Submit a story.

Accessibility 


$$
\text { H A R VAR D B US INESS SCHOOL }
$$

\section{Materiality in Corporate Governance: The Statement of Significant Audiences and Materiality}

Robert G. Eccles Tim Youmans

Working Paper 16-023 


\title{
Materiality in Corporate Governance: The Statement of Significant Audiences and Materiality
}

\author{
Robert G. Eccles \\ Harvard Business School \\ Tim Youmans \\ Harvard Business School
}

Working Paper 16-023 


\title{
Materiality in Corporate Governance: The Statement of Significant Audiences and Materiality
}

September 3, 2015

By

\author{
Robert G. Eccles and Tim Youmans
}

Harvard Business School

\begin{abstract}
Introduction
Under the prevailing ideology of "shareholder primacy" most boards of directors believe that they are prevented from considering stakeholders other than shareholders in determining material issues and materiality for strategy and reporting. New research is showing that legal foundations exist for directors to indeed consider other stakeholders. To many boards, this is new thinking. In order to assist boards in this new realm of taking into account multi-stakeholder significance, we have structured this paper in four parts and a conclusion. In Part I we review fiduciary duty focusing on to whom this duty is owed. In Part II, we review the relevance of materiality in corporate governance. In Part III, we review our audience-focused materiality determination approach and in Part IV we discuss the new idea of an annual board "Statement of Significant Audiences and Materiality." We conclude with some preliminary research results, ideas for future research, and next steps.

Much of the material presented in this paper has been adapted and updated from Chapter 5 of author Eccles' recent book, The Integrated Reporting Movement: Meaning Momentum Motives and Materiality (Chapter 5). ${ }^{1}$ Author Youmans was a significant contributor to Chapter 5. By way of a brief explanation, "integrated reporting," or an integrated report, is the combination of the traditional, financially-oriented annual report with the material parts of a corporation's sustainability report, showing the relationships that exist between the difference dimensions of performance. Many of the world's largest corporations are adopting integrated reporting. However, we strongly emphasize that the arguments presented in this paper are as relevant for "Form $10-\mathrm{K}$ and Form $20-\mathrm{F}^{\prime 2}$ reporting as they are for integrated reporting. While we will refer to integrated reporting from time to time throughout this paper, our key points about fiduciary duty and materiality in corporate governance apply to reporting in a totally general sense.

It is this general sense that describes the difference between Chapter 5 and this paper. While Chapter 5 looked at materiality and governance in the context of integrated reporting, this paper is focused on materiality in the context of corporate governance, with traditional, integrated, and sustainability reporting as equally applicable consequences. In our ongoing research into the role of the corporation in society, we have found that the materiality principles supporting integrated reporting, along with the principles underlying the idea of the corporation itself, apply to all listed corporations regardless of reporting regime or nationality.
\end{abstract}




\section{Fiduciary Duty}

The objective of the corporation, as a separate and potentially immortal legal person, is simply to survive and, if possible, to thrive. Since shareholders own only freely tradable rights (to vote, to claim residual assets, and to the wages of capital), the burdens of ownership and management of the corporation's assets are entrusted to the board of directors. This trust is commonly referred to as "fiduciary duty."

A prevailing ideology across the globe is that directors' fiduciary duty requires them to place primacy on shareholders' interests. Research is showing, however, that in every nation examined thus far, this is indeed ideology, not law. Shareholder value is an outcome of the corporation's use of capitals, not the objective of the corporation. ${ }^{3}$ Shareholders and providers of financial capital are but one audience of the corporation. As the corporation mobilizes financial, manufactured, intellectual, human, social and relationship, and natural capital, each capital has one or more stakeholders who have an interest in this form of capital.

Moreover, the potential immortality of the corporation implies that future generations are also stakeholders. Considering all possible combinations of issues and stakeholders, along financial and nonfinancial attributes (i.e., environmental, social and governance, or "ESG" issues), with current and future time frames, would make the directors' fiduciary task impossible, as corporations have limited resources and limited competencies to deploy against these capitals. In the face of these limited resources, directors must make choices as to which audiences are significant; these will be a subset of all of the firm's stakeholders. These "significant audiences" determine which issues are "material" to the ability of the corporation to sustain itself over a self-defined period of time. As the trustees of the corporation, directors too often focus on issues that are only material for short-term financial performance. We suggest that directors focus on significant audiences and this implies a broader range of issues, over a longer time frame, to be considered in determining materiality. Because shareholder primacy ideology has been widely perceived as a legal requirement, directors by and large have not seriously considered the full array of potential audiences that may be significant.

In order to set the global, country-by-country legal framework that allows directors to consider the universe of stakeholders in their materiality determination process, global research is being conducted. This research has shown, so far, in every jurisdiction across the world without exception that the board of director's primary duty is to the corporation itself as a separate legal person. The concept of corporate personhood, ${ }^{4}$ separate and apart from shareholders, from other providers of capital and from other stakeholders, is universal and underlies both limited liability and liquidity of freely tradable shareholder rights (i.e., "shares"). In some jurisdictions, most notably the United States, there is "primacy duality" in that directors' duty to the separate corporate person is co-equal to directors' duty to shareholders. In no jurisdiction is a duty to shareholders a higher duty than to the corporate person. In some jurisdictions, such as Brazil, the current legal definition of the corporate person includes the full range of potential stakeholders, such as employees, customers, and NGOs representing various interests of civil society. 


\section{The Relevance of Materiality in Corporate Governance}

Materiality, in its essence, is entity-specific, audience and time frame dependent, and ultimately based on the judgment of the board of directors. Materiality's guiding principle is conciseness. Boards that have the courage to be concise and limit reporting to only material information are also sending the meta-message that they have the ability to exercise this judgment-in other words, to govern. Determining materiality is at the essence of directors' fiduciary duty and it is the basis for establishing the legitimacy of the corporation's role in society.

In a background paper for "The International $<\mid R>$ Framework ( $<\mid R>$ Framework)," ${ }^{5}$ the International Integrated Reporting Council (IIRC) states:

Another unique feature of materiality for [corporate reporting] purposes is that the definition emphasizes the involvement of senior management and those charged with governance in the materiality determination process in order for the organization to determine how best to disclose its unique value creation story in a meaningful and transparent way. ${ }^{6}$

We think it possible to be more specific about the role of the board in determining materiality. In fact, we argue that the responsibility for making this determination ultimately lies with the board and that, in order to fulfill its primary fiduciary responsibility to the sustainability of the corporation, it must do so. However, in order to prescribe a more specific role for the board and to outline board tasks in the annual reporting cycle, we must first review its basic, if often mischaracterized, role as an actor in the social construction of materiality.

In one of the most important business books of all time, ${ }^{7}$ The Modern Corporation and Private Property, ${ }^{8}$ Adolf Berle and Gardiner Means identified three broad privileges granted to corporations by the State:

1. The ability to limit liability, or to socialize $\operatorname{losses}^{9}$, while privatizing profits, thus attracting risk capital. ${ }^{10}$

2. The ability of corporations to own other corporations, allowing for concentration of control disproportionate to share of risk capital. ${ }^{11}$

3. The separation of ownership rights from control rights, enabling freely tradable shares. ${ }^{12}$

Berle and Means went on to say that "The property owner who invests in a modern corporation so far surrenders his wealth to those in control of the corporation that he has exchanged the position of independent owner for one in which he may become merely [a] recipient of the wages of capital... [Such owners] have surrendered the right that the corporation should be operated in their sole interest." ${ }^{13}$ Since society has granted corporations these special privileges, corporations have a moral, if not a civic, duty to think not only of profits, but also of the good of society. ${ }^{14}$ This underpins the duty of corporations to not just "perform," but also to "report" material actions back to society beyond those that are profit-related. 
The duty of a corporation to take society's interest into account in exchange for these special privileges is held, in trust, by the board of directors. Through the corporate privilege of personhood granted by society, a corporation arrives at its own legal identity, separate from its shareholders, directors, managers, employees, and other stakeholders. As such, it has the capacity to survive many generations. In his book Firm Commitment, Professor Colin Mayer of Oxford University notes that the corporation's current decisions will have an impact long after the tenure of its current management and directors has expired and that, consequently, the board is the appropriate trustee of the firm's intergenerational commitment. ${ }^{15}$ This implies that director judgment must be informed by a keen sense of the social context within which the corporation is operating, further informing the board's oversight of the management team in formulating and implementing the company's strategy. It also implies that the board is responsible for taking a long-term view and ensuring that management is doing so, to the extent it deems necessary.

Narrowing down a long list to what ultimately passes the materiality threshold for corporate reporting purposes demands the exercise of judgment to separate the "material" from the "immaterial." The firm's ability to determine what is and is not material through its senior management and those involved in governance ${ }^{16}$ symbolizes its social agency. Since a given factor's relevance must be weighted by its importance to the company, "Judgment is applied in determining the information to disclose about material matters." ${ }^{17}$ While the firm may undertake an involved stakeholder engagement process, the board, in carrying out its fiduciary duty, makes the ultimate decision as to what is material to its strategy.

\section{Audience-Focused Materiality Determination}

Materiality forms the conceptual bedrock of corporate reporting, yet no authoritative definition of it exists. In "Securities Regulation,"18 Louis Loss points out that the legal field offers no specific definition of the word. Court opinions on materiality have merely sketched its conceptual contours. Every time materiality has been relevant to a legal case in the U.S., the court has opined that it must be decided on a case-by-case basis, as is the precedent when deciding fraud cases. ${ }^{19}$ The U.S. Supreme Court has also asserted that this determination must be based on both qualitative and quantitative factors based on the "total mix" of information made available. ${ }^{20}$ Further complicating the "total mix" standard set by the Supreme Court for evaluating potentially material omissions or misstatements, the Court left open the issue of "circularity" in its definition of materiality. ${ }^{21}$ Finally, the courts have also made clear that materiality must be determined with complete clarity. These opinions do not discuss "degrees" of materiality; materiality is binary. A fact either is material, in which case it must be reported, or is not material, in which case it does not need to be reported.

These materiality assessments are made by the corporation itself. Since investors have no voice in a company's materiality determination process other than through lawsuits (which lead to further guidance instead of specific answers), it is management's, and ultimately the board's, responsibility to ascertain what information its "reasonable investors" 22 would want to know. In the end, materiality is 
determined by the corporation and it is entity-specific. ${ }^{23}$ While there may be no easy rule to follow in determining materiality, how companies go about making the ultimate decision of which issues are material for reporting purposes should be a clearly defined process with solid lines of responsibility.

Because materiality is a firm-specific social construct, it poses certain challenges for corporate reporting. Since every board and management team protects a unique brand, what the corporation symbolizes for society is unique to each firm. Each firm can define its own materiality threshold within the boundaries of accepted and evolving standards. In "Westphalian" ${ }^{24}$ terms, materiality for the firm becomes materiality for its significant audiences.

The involvement of "audiences" begs the question of to whom the firm is reporting. In the context of materiality for corporate reporting, one must ask, "Who does the board address when it determines which issues are material, and which issues are not?" Although providers of financial capital are clearly a significant audience, other audiences also exert pressure on the firm's selection of material issues. Various stakeholders wield varying degrees of influence on the providers of capital and the firm itself, and the implications of that influence are often too great to ignore. Consequently, when the firm decides what information is material, it must, for its own good, take into account the perspectives of stakeholders beyond those who provide financial capital.

The $<\mid \mathrm{R}>$ Framework presents in its section on "Materiality" a four-step process to determine what information is material:

1. "Identifying relevant matters based on their value to affect value creation...,

2. Evaluating the importance of relevant matters in terms of their known or potential effect on value creation...

3. Prioritizing the matters based on their relative importance...

4. Determining the information to disclose about material matters." 25

We suggest beginning the above materiality determination process with a preliminary step: "Identify audiences relevant to the corporation, their interests (including where they conflict), and the relative weight attached to each."

Our recommended preliminary step is rarely done with any degree of rigor for two reasons. The first is the prevailing ideology that the fiduciary duty of directors requires them to place primacy on shareholders' interests. Many firms address broad stakeholder interests by saying something general like, "We are committed to delivering excellent returns for our shareholders and we firmly believe that addressing stakeholders' interests further enables us to do so." While this sounds "nice" and is consistent with the emerging rhetoric in support of the "business case for sustainability reporting," 26 it ignores the fact that trade-offs often exist, particularly in the short term. ${ }^{27}$ Moreover, not only are there trade-offs between providers of financial capital and other audiences, there are trade-offs between one type of provider of financial capital and another (e.g., equity vs. debt), as well as between different audiences (e.g., those focused on an environmental issue vs. those focused on a social issue). 


\section{The Statement of Significant Audiences and Materiality}

Determining the relative importance of different providers of financial capital and of other audiences is ultimately a responsibility of the board. What does this mean in operational terms? We suggest that annually the board issue a forward-looking "Statement of Significant Audiences and Materiality (The Statement)." This statement will inform management, providers of financial capital, and all other stakeholders of the audiences the board believes are important to the survival of the corporation.

Introduced in Chapter 5 "Materiality" in author Eccles' recent book, The Statement is a one page document issued annually by the board of directors of a corporation. The Statement is where the board identifies significant audiences and time frames, how the board defines the role of that corporation in society, and is the foundation for the company's corporate reporting. The Statement is essentially the board's report on its responsibility to the corporation for the determination of materiality.

While management can play a significant role in preparing The Statement, it is ultimately a statement of the board, somewhat analogous to the annual financial audit. While management is deeply involved in the audit and, in the U.S., the CEO and CFO must personally sign off on the adequacy of a company's internal control systems, it is the Audit Committee of the board that selects and engages the audit firm and signs off on the scope of the audit. The Statement, like the audited financial statement, is ultimately a responsibility of the board - not management. ${ }^{28}$

When issuing "The Statement" the board must make judgments, tough judgments, since it cannot claim that all audiences are significant. Saying "We will create value for our shareholders by meeting the needs of all of our stakeholders" is not a Statement, it is puffery. ${ }^{29}$ It is greenwashing. A corporation, no matter how large, has limited resources and has to set priorities in terms of how they are allocated. For example, a corporation may choose to lay off employees or cut back on its R\&D expenses in order to meet its quarterly earnings target. Implicitly, this is making short-term shareholders a more significant audience than employees or than long-term shareholders who would benefit from this research. Or the firm can have a different view, such as cutting dividends before "downsizing." Short-term shareholders may not like this decision, but long-term investors (e.g., pension funds) might applaud it.

The Statement should also be clear about the time frames in which the corporation evaluates the impact of its decisions on its significant audiences. A 10-year horizon is very different than a one-year horizon. Again, the board, entrusted with the interest of the corporate person, has the right to make this timeframe determination. It just needs to be transparent about what it is.

It is the right of the corporation to make these judgments and it is the responsibility of the board to do so. The Statement is the basis for an open and honest conversation between the corporation and all of its stakeholders. What is important is that The Statement clearly communicates the board's view of the company's priorities by identifying the limited number of which it regards as its significant audiences and, by implication, which are not. Then shareholders (of all kinds and classes), bondholders, and the company's many other audiences can make their own resource allocation decisions in terms of how they engage, or not, with the corporation. Exercising this judgment requires board discipline, a willingness to 
be transparent, and an acceptance of the fact that audiences not deemed significant will object. They will want to engage with the corporation on this judgment and the corporation has an obligation to engage back with these "important but not significant" audiences. But the board doesn't have an obligation to change its mind. Clearly there are other audiences that are important to varying degrees, and the issues they care about may be socially significant ones, yet not material to the company. ${ }^{30}$ The company should report on these issues in its sustainability report. The material issues based on the chosen significant audiences and timeframes belong in the annual financial, or integrated, report.

Recent evidence shows that investors have a significant latent appetite for the reporting of material ESG information that lies beyond the financials. The Statement can be a means for meeting the demand by this audience for nonfinancial information. According to a $2014 \mathrm{EY}$ survey on "Tomorrow's Investment Rules," institutional investors want a clearer view of what is material and want it directly from the company:

Materiality is a key concept that emerged from this survey. Investors were more likely to value information which came directly from the company itself rather than from third-party sources. In addition, among those that never consider ESG information in their decision-making process, the main reason for rejecting it was that they felt it was not material. ${ }^{31}$

Through The Statement, the board describes the role of the corporation in society: whose interests are being served and in what time frame. The broader understanding of the role of the corporation in society is one of the pressing issues facing the growing sustainable development movement. It will become even more so when the United Nations ratifies the Sustainable Development Goals (SDGs) in September of 2015. As social expectations continue to rise about how corporations, especially the world's largest corporations, can contribute to a more sustainable society, companies have no choice but to respond. Ultimately, the company's license to operate comes from civil society. However, the company needs to be clear on which issues are a priority, as determined by its chosen significant audiences, and which are not. Through The Statement of Significant Audiences and Materiality, the board presents a clear view of their company's role in society which will guide both management decisions and its interactions with its many audiences.

\section{Conclusion}

We have argued that the board's duty is to the interests of the corporation rather than the particular audience of shareholders, as is commonly believed. While the board can choose to deem shareholders as the only significant audience, it does not have to do so. The board must simply decide which audiences are most significant for the ability of the corporation to create value over the short, medium, and long term. Once it has done so, it has laid the foundation of the materiality determination process for corporate reporting.

Unlike most academic papers, this one doesn't simply end in a call for further research, although we certainly plan to do that. Rather, this is one element of an action-oriented initiative called "The 
Statement of Significant Audiences and Materiality Campaign (Statement Campaign)" to ensure that the ideas in this paper get translated into practice. The Statement Campaign is articulated in a post titled "Why Boards Must Look Beyond Shareholders" in the "Big Ideas: Sustainability" section of the MIT Sloan Management Review website. In this post we describe our current and ongoing global research into fiduciary duty with respect to significant audiences, and some preliminary findings. In summary:

Over the past 12 months, we have gathered legal memos provided by leading law firms in 20 countries about the fiduciary duty of board directors in their respective countries. The template for these memos was developed in collaboration with Linklaters, a renowned global law firm. What's more, we have commitments to produce these memos from law firms in all G20 countries and a number of others. To date, this research has shown - without exception - that the board directors' primary duty is to the corporation itself as a separate legal person.

In some jurisdictions, most notably the United States, there is "primacy duality" in that the directors' duty to the separate corporate person is coequal to directors' duty to shareholders. In no jurisdiction is a duty to shareholders a higher duty than to the corporate person. In some jurisdictions, such as Brazil, fiduciary duty explicitly includes the corporation's obligations to nonfinancial stakeholders.

We are conducting this ongoing research project jointly with The American Bar Association's "Sustainable Development Task Force (Task Force)," and the UN Global Compact, and with support from and in coordination with the Principles for Responsible Investment and UNEP Finance Initiative. Other steps in this campaign include mobilizing investors to ask company boards to issue The Statement and finding companies who will lead in doing so.

This database of legal memos, which will be freely available to all on the Task Force's website, will continue to be updated as more country memos are added and existing ones updated. It is our hope that this global collection of legal memos on fiduciary duty will become a resource for other researchers, advisors, investors, board members, executives, regulators, and other stakeholders, sparking a global discourse on the role of the corporation in society.

These legal memos lend themselves to much deeper analysis and we welcome others to do so. Among many areas for research that may arise from The Statement Campaign, we see immediate opportunities in four specific areas:

1. Variations in the extent to which country laws require that directors take account of other stakeholders' interests,

2. Differences in civil vs. common law,

3. Differences in developed vs. developing countries, and

4. Digging deeper into "primacy duality." 
The goal of the Statement Campaign, further propelled by complementary and, frankly, by opposing, research, is that by 2025 the board of directors of every listed company will be issuing an annual Statement of Significant Audiences and Materiality. Given the growing demand for improved corporate accountability to audiences other than shareholders, ${ }^{32}$ the Statement is the starting point for a company to do so.

Robert G. Eccles is a Professor of Management Practice at Harvard Business School, and Tim Youmans is a Researcher at Harvard Business School. They are research collaborators and global experts in materiality. They can be reached at tyoumans@hbs.edu and reccles@hbs.edu. The authors invite readers to submit to commentary here on the Sloan Management Review website.

\footnotetext{
${ }^{1}$ Adapted and updated from Chapter 5 of Eccles, Robert G., Michael P. Krzus, and Sydney Ribot. The Integrated Reporting Movement: Meaning, Momentum, Motives and Materiality. Chapter 5: John Wiley \& Sons, 2014. ${ }^{2}$ By U.S. Securities and Exchange Commission Rules, U.S. listed domestic companies must submit annual reports on Form 10-K, and foreign companies listed on U.S. exchanges must submit annual reports on Form 20-F. 3 "In other words, once again beyond legal requirements, the interests of others, including human rights, derive from those of the corporations' shareholders. So the argument for shareholder value has been profoundly influential in shaping the laws and conventions that govern the conduct of our corporations. So elegant is the argument that I will employ it in coming to the exact opposite conclusion (pp. 31-32)... Shareholder value is an outcome not an objective. It should not drive corporate policy but be treated as a product of it. (p.261)" Mayer, Colin. "Firm Commitment: Why the Corporation is Failing Us and How to Restore Trust in It." (2013). See also Stout, Lynn "The Shareholder Value Myth: How Putting Shareholders First Harms Investors, Corporations, and the Public." (2012)

4 "The Misleading Metaphor of Shareholder 'Ownership' ... describes shareholders as "owners" of corporations. As a legal matter, the claim that shareholders "own" the corporation is obviously incorrect. Corporations are independent legal entities that own themselves; shareholders only own a security, called "stock," with very limited legal rights. [Footnote on p. 804: "This metaphor may have roots in the nineteenth century, when most corporations were closely held firms with only a single shareholder or a very small number of shareholders. In such firms, shareholders exercise far more control, and it may make more sense to think of them as "owners."] "The Mythical Benefits of Shareholder Control." Lynn A. Stout, Virginia Law Review, Vol. 93, No. 3 (May, 2007) , p. 804, http://www.jstor.org/stable/25050361.

5 "The International < $<$ R Framework", The International Integrated Reporting Council, http://integratedreporting.org/resource/international-ir-framework/

${ }^{6}$ International Integrated Reporting Council. "Materiality background paper

for $\langle$ IR>," p.1, http://www.theiirc.org/wp-content/uploads/2013/03/IRBackground-

Paper-Materiality.pdf

7 “'In the time to come this volume may be proclaimed as the most important work bearing on American statecraft ... and will mark a sharp turning point in fundamental, deep-thrusting thinking about the American State and American civilization.' Few books receive reviews like this in the New York Herald Tribune [Charles Beard, 'Who Owns - and Runs - the Corporations', February 19, 1933, book review section], and still fewer that are academic research monographs. But so a book that was destined to establish a new field of scholarship was greeted with its publication in 1932...This book will perhaps rank with Adam Smith's Wealth of Nations as the first detailed description in admirably clear terms of a new economics epoch"' [Frank and Meyers, 1933, Yale Law Review, 42,
} 
989-1000]. Mayer, Colin. Firm Commitment: Why the Corporation is Failing Us and How to Restore Trust in It. Oxford University Press, 2013.

${ }^{8}$ Berle, Adolf Augustus, and Gardiner Coit Means. The Modern Corporation and Private Property. Transaction Publishers, 1991 (10th version, original published in 1933).

${ }^{9}$ The ability to limit liability, though bankruptcy protection, is common to sole proprietors, closely held companies and individuals, as well as corporations. A key difference is that the corporation's control group (officers and directors) are able to socialize the losses on others' capital investment, not their own capital investment. ${ }^{10}$ From American and English law, "the very existence of the corporation was conditioned on a grant from the state. This grant created the corporation and set it up as a separate legal person independent of any associates [investors and managers]", [also contemporarily termed "corporate personhood."] From this state granted personhood "privilege ... flowed a limited liability of associates ... a stockholder was not liable for any of the debts of the enterprise and he could thus embark a particular amount of capital in the corporate affairs without becoming responsible, beyond this amount, for the corporate debts." Berle and Means, The Modern Corporation, p. 120-121. Regarding the role of limited liability in attracting risk capital in Easterbrook, Frank H., and Daniel R. Fischel. "Limited liability and the corporation." U. Chi. L. Rev. 52 (1985): 89.p. 636, "Third, limited liability enables the transfer of securities on a trading market, ensuring liquidity. Absent limited liability, shares would be difficult to value because they would carry the potential of excess liabilities." The role of limited liability in attracting risk capital has also been shown mathematically in Merton, Robert C. "An Intertemporal Capital Asset Pricing Model," Econometrica, Vol. 41, No. 5 (Sep., 1973), which concludes on page 885 that "An intertemporal model of the capital market has been developed which is consistent with both the expected utility maxim and the limited liability of assets [equities]."

${ }^{11}$ Also derivative of corporate personhood, corporations can exert "Control Through a Legal Device. In the effort to maintain control of a corporation without ownership of a majority of its stock, various legal devices have been developed. Of these, the most important among the very large companies is the device of "pyramiding." This involves the owning of a majority of the stock of one corporation which in turn holds a majority of the stock of another-a process which can be repeated a number of times. An interest equal to slightly more than a quarter or an eighth or a sixteenth or an even smaller proportion of the ultimate property to be controlled is by this method legally entrenched." Berle and Means, The Modern Corporation, p. 69.

12 "The separation of ownership from management and control in the corporate system has performed this essential step in securing liquidity. It is the management and "control" which is now wedded to the physical property. The owner has no direct personal relation to it and no responsibility toward it. The management is more or less permanent, directing the physical property which remains intact while the participation privileges of ownership are split into innumerable parts ["dispersed ownership"]-' shares of stock'-which glide from hand to hand [as a "token"], irresponsible and impersonal... Most striking of all, a liquid token acquires a value purely and simply because of its liquidity". Berle and Means, The Modern Corporation, pp. 250-251. As cited above, the separation of ownership from control combined with personhood-derived limited liability enables the free trading of shares and liquid market for these shares.

${ }^{13}$ Berle and Means, The Modern Corporation, p. 5

${ }^{14}$ Lynn Stout (The Shareholder Value Myth, 2012) describes that the foundation of the "profit maximizing," thus stakeholder minimizing, corporate governance is the self-disproving view of social interaction symbolized by "Homo economicus": "Let us see how our friend Homo economicus stacks up against the list [of clinical sociopathic behaviors]. Lack of remorse (item 7)? Obviously; why would Homo economicus feel bad just because he hurt or misled another, if he advanced his own material welfare? Irresponsibility and reckless disregard for the safety of others (items 5 and 6)? Homo economicus feels responsible for, and cares about, no one but himself. Deceitfulness (item 2)? Homo economicus is happy to lie any time it serves his interests. Failure to conform to social norms with respect to lawful behaviors (item 1)? Whenever and wherever the police aren't around describes Homo economicus. Although Homo economicus is neither cranky nor impulsive-items 3 and 4 -he has five of the seven characteristics on the list. Unburdened by pity or remorse, he will lie, cheat, steal, neglect duties, break promiseseven murder-if a cold calculation of the likely consequences leads him to conclude that he will be better off. Like any sociopath, Homo economicus lacks a conscience." It is clear that most modern corporate board members are not Homo economicus, and it is within the norms of the modern corporate social construct to reciprocate back to society, beyond pure profit making. Stout, Lynn A. "Taking conscience seriously." Moral Markets: The Critical Role of Values in the Economy. Princeton University Press, Princeton (2007): 157-172. 
${ }^{15}$ Specifically, Mayer advocates a two-tier form of board governance called a "trust firm," somewhat similar to the German board model ("Ownership and control of German corporations," Mayer \& Franks, 2001). Given that the trust firm is not (yet) the standard in the U.S. and other corporate domiciles, we feel that Mayer's "trust theory of the stratified Board" applies to today's current directors: “...the corporation is a rent extraction vehicle for the shortest term shareholders. The power of owners [controllers] with the shortest time horizon not only concentrates control and wealth amongst them and their agents, but also is the source of failure to account for the interest of any generation but their own. Competition may confer some benefits on their customers, but by focusing the horizon of the firm so closely on the near term, the wellbeing of all but the most immediate generation is disregarded. We should not therefore rely on competition to be the guardian of our offspring ... [The corporation will have to turn to trustees who are the custodians of the firm's values] to restrain it from defaulting on the future. Their presence changes the nature of the corporation from being a pure agency one, in which the directors act as agents of the shareholders, to a mixed trust arrangement in which the [Board] acts in behalf of the designated stakeholders of the corporation." It is our belief that these stakeholders are material and significant audiences that the firm defines and in its corporate reporting process. Mayer, Firm Commitment, pp. 240, 244-245. ${ }^{16}$ The International Integrated Reporting Council. "Materiality: Background Paper for $\langle\mid R\rangle$, , p. 2, http://www.theiirc.org/wp-content/uploads/2013/03/IR-Background-Paper-Materiality.pdf, accessed March 2014. ${ }^{17}$ Ibid., p. 19.

${ }^{18}$ Loss, Louis, Joel Seligman, and Troy Paredes. Securities Regulation. New York: Little, Brown and Company, 1961. p.1436.

19 "It is said that a fraudulent representation must be material to have that effect. But how are we to decide whether it is material or not? It must be by an appeal to ordinary experience to decide whether a belief that the fact was as represented would naturally have led to, or a contrary belief would naturally have prevented, the making of the contract." (Holmes, Oliver Wendell. "The common law." (1881) in Gutenberg Project version: [308] LECTURE IX. CONTRACT.- III. VOID AND VOIDABLE.). This is one of the first commercial law references to materiality. Later cases such as Basic Inc. v. Levinson, 485 U.S. 224, 108 S. Ct. 978, 99 L. Ed. 2d 194 (1988) and TSC Industries, Inc. v. Northway, Inc., 426 U.S. 438, 96 S. Ct. 2126, 48 L. Ed. 2 d 757 (1976), as well as post-Securities Act regulations, arguably, stand on the shoulders of Holmes' legal construction of commercial materiality.

20 "a showing of a substantial likelihood that, under all the circumstances, the omitted fact would have assumed actual significance in the deliberations of the reasonable shareholder. Put another way, there must be a substantial likelihood that the disclosure of the omitted fact would have been viewed by the reasonable investor as having significantly altered the 'total mix' of the information made available." TSC Industries, Inc. v. Northway, Inc., 426 U.S. 438, 96 S. Ct. 2126, 48 L. Ed. $2 d 757$ (1976) at 449.

${ }^{21}$ The circularity of this [TSC v. Northway] definition leaves the question of what determines the "total mix" of information unanswered. Does it refer to all other material information except for the piece in question? If so, upon what basis was all this information judged to be material in the first place, since the "total mix" of information must be constructed one piece at a time. Was the first piece of information deemed material because it was important to a reasonable investor, and then all other information is judged in the context of increasing amounts of information? Conceivably, whether a piece of information is material or not would be a function of how much other information is available. When little information is available, the relevance of an additional bit of information can be high. When a substantial amount of information is available, an additional piece may be less relevant. If the total mix of information also includes immaterial information, then the question arises regarding the basis on which the total mix is built.

${ }^{22}$ See note 20 , TSC v. Northway.

${ }^{23}$ The phrase "entity-specific" is used in the Financial Accounting Standards Board definition of materiality. "Information is material if omitting it or misstating it could influence decisions that users make on the basis of the financial information of a specific reporting entity. In other words, materiality is an entity-specific aspect of relevance based on the nature or magnitude or both of the items to which the information relates in the context of an individual entity's financial report. Consequently, the Board cannot specify a uniform quantitative threshold for materiality or predetermine what could be material in a particular situation." Financial Accounting Standards Board. Statement of Financial Accounting Concepts No. 8, p. 17, http://www.fasb.org/cs/BlobServer?blobkey=id\&blobnocache=true\&blobwhere=1175822892635\&blobheader=ap plication\%2Fpdf\&blobheadername2=Content-Length\&blobheadername1=Content-

Disposition\&blobheadervalue2=210323\&blobheadervalue1=filename\%3DConcepts_Statement_No_8.pdf\&blobcol 
$=$ urldata\&blobtable=MungoBlobs, accessed May 2014. For another discussion on materiality for nonfinancial information see, Eccles, Robert G., Michael P. Krzus, and George Serafeim. "A Note on Materiality for Nonfinancial Information." Harvard Business School Note N9-314-033, November 2013.

${ }^{24}$ In academic circles, the phrase "Westphalian Sovereignty" is sometimes summarized, as "The religion of the prince is the religion of the place." Arguably, the source of the concept of "sovereignty," the Peace of Westphalia of 1648 was: "The end of the Thirty Years War [and] brought with it the final end of the medieval Holy Roman Empire. Authority for choosing the religion of the political unit was given to the prince of that unit and not to the Hapsburg Emperor or the Pope. No longer could one pretend there was religious or political unity in Europe. Authority was dispersed to the various kings and princes, and the basis for the sovereign state was established." Russett, Bruce, Harvey Starr, and David Kinsella. World Politics: The Menu for Choice. Cengage Learning, 2005. 25 "The International <IR> Framework", The International Integrated Reporting Council, Guiding Principles 3.18, p.

18.

26 “... the current state of sustainability reporting is in some ways, 'contra-materiality' when the proper meaning of the term 'materiality' is understood. In this post we will illustrate this point using the examples of GE and of the Dow Jones Sustainability Index (DJSI)." Eccles, Robert G. and Youmans, Tim, "In this corner, DJSI; and in this corner, materiality. Ding!", Materilaitytracker, User Views, July 2015, http://www.materialitytracker.net/user-

views/current/

${ }^{27}$ Eccles, Robert G. and George Serafeim. "The performance frontier." Harvard Business Review 91, no. 5 (2013).

${ }^{28}$ Sarbanes-Oxley Act of 2002, PL 107-204, 116 Stat 745, Section 301, Paragraph 2: "RESPONSIBILITIES RELATING TO REGISTERED PUBLIC ACCOUNTING FIRMS. - The audit committee of each issuer, in its capacity as a committee of the board of directors, shall be directly responsible for the appointment, compensation, and oversight of the work of any registered public accounting firm employed by that issuer (including resolution of disagreements between management and the auditor regarding financial reporting) for the purpose of preparing or issuing an audit report or related work, and each such registered public accounting firm shall report directly to the audit committee." RESPONSIBILITIES RELATING TO REGISTERED PUBLIC ACCOUNTING FIRMS. - The audit committee of each issuer, in its capacity as a committee of the board of directors, shall be directly responsible for the appointment, compensation, and oversight of the work of any registered public accounting firm employed by that issuer (including resolution of disagreements between management and the auditor regarding financial reporting) for the purpose of preparing or issuing an audit report or related work, and each such registered public accounting firm shall report directly to the audit committee.

${ }^{29}$ For an analysis of "puffery" in the context of corporate governance, see: Eccles, Robert G. and Youmans, Tim, "Implied Materiality and Material Disclosures of Credit Ratings," Harvard Business School Working Paper 15-079, April 9, 2015

${ }^{30}$ For information on a new tool that corporations may use to help the evaluation of audience significance, see Chapter 6, "The Sustainable Value Matrix" in: Eccles, et al. The Integrated Reporting Movement: Meaning, Momentum, Motives and Materiality.

${ }^{31}$ E\&Y. "Tomorrow's investment rules: a global survey." p. 2, http://www.ey.com/Publication/vwLUAssets/EYInstitutional-Investor-Survey/\$FILE/EY-Institutional-Investor-Survey.pdf, accessed May 2014.

32 "Actions taken by banks to prevent future litigation issues included everything from changing remuneration policies to a greater focus on 'non-financial metrics', ...", Laura Noonan, "Bank litigation costs hit $\$ 260 \mathrm{bn}-$ with \$65bn more to come", Financial Times, August 23, 2015 